\title{
Pengaruh Return on Assets, Current Ratio dan Firm Size Terhadap Prediksi Kebangkrutan Dengan Struktur Modal sebagai Variabel Moderasi
}

\section{The Effect of Return on Assets, Current Ratio and Firm Size on Bankruptcy Prediction with Capital Structure as Moderation Variable}

\author{
Mita Ayu Safitri \& Indah Yuliana* \\ Jurusan Manajemen, Fakultas Ekonomi, Universitas Islam Negeri Maulana Malik Ibrahim Malang, \\ Indonesia
}

Email: indahoty@manajemen.uin-malang.ac.id

\begin{abstract}
Abstrak
Penelitian ini bertujuan untuk mengetahui: hasil prediksi kebangkrutan pada perusahaan Industri Dasar dan Kimia yang terdaftar di BEI periode 2016-2019, mengetahui pengaruh return on asset, current ratio dan ukuran perusahaan terhadap prediksi kebangkrutan, serta mengetahui pengaruh struktur modal dalam memoderasi hubungan return on asset, current ratio dan ukuran perusahaan terhadap prediksi kebangkrutan. Berdasarkan metode purposive sampling, diperoleh sampel sejumlah 38 perusahaan. Metode analisis yang digunakan adalah metode statistic deskriptif dengan menggunakan alat analisis Regresi Moderasi. Hasil penelitian ini menunjukkan bahwa current ratio berpengaruh positif secara signifikan terhadap financial distrees. Return on asset dan ukuran perusahaan tidak berpengaruh terhadap financial distrees. Struktur modal mampu memoderasi hubungan return on asset terhadap financial distress. Struktur modal tidak mampu memoderasi hubungan current ratio dan ukuran perusahaan terhadap financial distress pada pada perusahaan sektor industri dasar dan kimia. Dengan menggunakan model Grover dapat diketahui bahwa dari tigapuluh delapan sampel penelitian semua perusahaan tidak berpotensi bangkrut.
\end{abstract}

Kata Kunci: ROA; CR; Ukuran Perusahaan; Financial Distrees; DER.

\begin{abstract}
This study aims to determine: the prediction results of bankruptcy in basic and chemical industry companies listed on the IDX for the 2016-2019 period and to determine the effect of return on assets, current ratio and company size on financial distress. Based on the purposive sampling method, there were 38 companies sampled. The method of analysis used is descriptive statistical method using Moderated Regression analysis tools. The results of this study indicate that the current ratio has a significant positive effect on financial distrees. Return on assets and company size have no effect on financial distrees. Capital structure is able to moderate the relationship between return on assets and financial distress. The capital structure is unable to moderate the relationship between current ratios and company size to financial distress in basic industrial and chemical companies. By using the Grover model, it can be that of the thirty eight samples all companies have no potential.
\end{abstract}

Keywords: ROA; CR; Firm Size; Financial Distrees; DER.

How to Cite: Safitri, M.A \& Yuliana, I. (2021). Pengaruh Return On Assets, Current Ratio Dan Firm Size Terhadap Prediksi Kebangkrutan Dengan Struktur Modal Sebagai Variabel Moderasi. 7(1): 90-99. 


\section{PENDAHULUAN}

Keberhasilan maupun kegagalan dalam mempertahankan suatu usaha dapat terjadi kapan saja karena perusahaan tidak dapat memprediksi apa yang akan terjadi di masa mendatang. Apalagi di era globalisasi ini, kondisi perekonomian selalu mengalami perubahan. Kondisi tersebut sering kali mempengaruhi kinerja keuangan. Jika perusahaan tidak mampu mengelolanya dengan baik maka kinerja keuangan akan mengalami penurunan dan akan berimbas pada potensi kebangkrutan (financial distrees). Financial distress ini dipengaruhi oleh faktor internal dan eksternal. Faktor internal meliputi penggunaan struktur modal yang kurang efisien, besarnya jumlah hutang dan kerugian operasional yang dialami perusahaan. Sedangkan faktor eksternal meliputi tingkat bunga pinjaman yang semakin meningkat. Perusahaan perlu melakukan penilaian kinerja keuangan agar dapat mengetahui kondisi perusahaannya apakah dalam kondisi yang sehat atau tidak sehingga perusahaan dapat terhindar dari kondisi-kondisi yang dapat menyebabkan kebangkrutan.

Fenomena mengenai kebangkrutan terjadi pada perusahaan manufaktur sektor industri dasar dan kimia. Ada beberapa sub sektor yang terancam bangkrut didalam sektor ini. Pertama, industri semen. Kondisi pasar semen domestik sangat memprihatinkan atau terancam bangkrut dikarenakan semen asal China gencar melakukan penjualan dengan harga dibawah pasaran di pasar semen lokal atau dikenal dengan predatory pricing (Liputan6: 2019). Dampak yang terjadi adalah menurunnya penjualan dan kapasitas produksi semen dalam negeri sehingga berimbas pada potensi kebangkrutan. Kedua, industri logam. Akibat mahalnya harga gas membuat biaya produksi dan biaya bahan baku industri ini membengkak dan terancam bangkrut. I Made Dana Tangkas (JawaPos: 2018) mengatakan bahwa jika dibandingkan dengan negara Jepang, Rusia dan ASEAN, harga gas di Indonesia jauh lebih mahal yaitu sebesar USD 9,5 per MMBTU. Adanya program hilirisasi yang belum diatur oleh sektor yang berwenang dan kurangnya penerapan SNI dalam mengendalikan importisasi baja juga menghambat industri ini, sehingga akan berujung pada kerugian material dan kebangkrutan (Silmy, Obrolanbisnis, 2019).

Dalam teori pecking order, perusahaan yang memiliki profitabilitas yang tinggi akan menggunakan sedikit hutang. Teori ini menunjukkan urutan prioritas penggunaan dana yang disukai oleh perusahaan. Dalam teori sinyal (signaling theory), setiap perusahaan akan memberikan informasi mengenai kondisi perusahaannya kepada pihak eksternal. Informasi tersebut dapat berupa sinyal positif (good news) maupun sinyal negatif (bad news). Rasio keuangan yang terdapat pada laporan keuangan dapat dijadikan sebagai media informasi untuk mengetahui adanya sinyal kebangkrutan perusahaan. Rasio keuangan yang sering digunakan adalah rasio profitabilitas dan likuiditas. Selain itu, prediksi kebangkrutan juga menggunakan ukuran perusahaan.

Penelitian yang dilakukan oleh Khusnul dan Indah (2020), Adinda, et al (2017), Srikalimah (2017), Deanisyah dan Erinos (2020), Rendra (2016) serta Alfinda, et al (2018) menemukan bahwa rasio profitabilitas yang diproksikan dengan ROA berpengaruh negatif dan signifikan terhadap prediksi kebangkrutan. Berbeda dengan penelitian Lamria (2015), Fitri (2016), dan Kanya et al. (2014) menemukan bahwa profitabilitas tidak berpengaruh terhadap kondisi kebangkrutan. Sedangkan untuk rasio likuiditas yang dilakukan oleh Widhy dan Nadia (2019), Kanya et.al (2014), Stephani et.al (2020) serta Yeni (2015) mengungkapkan bahwa rasio likuiditas berpengaruh signifikan terhadap financial distrees. Hasil yang berbeda ditemukan oleh Fifi (2016), Adinda, et al (2017), dan Srikalimah (2017) bahwa likuiditas tidak memiliki pengaruh yang signifikan terhadap financial distress. Selain itu ukuran perusahaan juga dapat digunakan sebagai alat untuk 
memprediksi kebangkrutan. Penelitian yang dilakukan oleh Ni Wayan dan Ni Ketut (2014), Orchid (2014), Agusti (2013) serta Widhy dan Nadia (2019) menyatakan bahwa ukuran perusahaan berpengaruh negatif dan signifikan terhadap financial distrees. Berbeda dengan penelitian oleh Adinda, et al (2017) dan Stephani et.al (2020) mengatakan bahwa ukuran perusahaan tidak mempengaruhi financial distress.

Penggunaan biaya dalam struktur modal akan mempengaruhi adanya potensi kebangkrutan perusahaan. Dalam penelitian yang dilakukan oleh Khusnul dan Indah (2020) menemukan bahwa struktur modal yang efektif mampu memoderasi hubungan profitabilitas terhadap prediksi kebangkrutan. Akmalia (2020) dan Andre (2013) mendukung pernyataan tersebut dimana peneliti menyatakan bahwa struktur modal memiliki pengaruh yang signifikan terhadap potensi kebangkrutan. Patrisius Gerdian (2016) menemukan bahwa terdapat metode yang paling akurat dalam mengukur prediksi kebangkrutan dengan nilai akurasi sebesar $100 \%$ dan masing-masing nilai kesalahan tipe I dan tipe II sebesar 0\% yaitu metode Grover (G-Score). Penelitian ini didukung oleh Heni (2017), Mauli Sari dan Irni Yunita (2019) yang menyatakan bahwa metode G-Score merupakan model prediksi yang paling sesuai karena mempunyai tingkat akurasi sebesar $100 \%$.

Berdasarkan fenomena dan penelitian terdahulu diatas, peneliti tertarik menggunakan struktur modal sebagai variabel moderasi karena pada penelitian sebelumnya banyak yang belum memperhatikan variabel struktur modal dalam memoderasi hubungan current ratio dan ukuran perusahaan terhadap financial distrees. Sehingga menjadi suatu kebaharuan bagi peneliti untuk menguji penelitian tersebut. Tujuan dari penelitian ini yaitu: (1) Untuk mengetahui hasil prediksi kebangkrutan pada perusahaan Industri Dasar dan Kimia yang terdaftar di BEI tahun 2016-2019; (2) Untuk mengetahui pengaruh profitabilitas (ROA), likuiditas (CR) dan ukuran perusahaan terhadap prediksi kebangkrutan; (3) Untuk mengetahui struktur modal mampu memoderasi hubungan profitabilitas (ROA) terhadap prediksi kebangkrutan; (4) Untuk mengetahui struktur modal mampu memoderasi hubungan likuiditas (CR) terhadap prediksi kebangkrutan; (5) Untuk mengetahui struktur modal mampu memoderasi hubungan ukuran perusahaan terhadap prediksi kebangkrutan.

\section{METODE PENELITIAN}

Penelitian ini merupakan penelitian kuantitatif. Populasi dalam penelitian ini adalah seluruh perusahaan sektor industri dasar dan kimia yang terdaftar di Bursa Efek Indonesia pada periode 2016-2019 sejumlah 69 perusahaan. Teknik pengambilan sampel pada penelitian ini menggunakan purposive sampling dengan kriteria sebagai berikut:

\begin{tabular}{llc}
\hline No. & \multicolumn{1}{c}{ Keterangan } & Jumlah Perusahaan \\
\hline 1. & $\begin{array}{l}\text { Perusahaan industri dasar dan kimia yang terdaftar di BEI selama } \\
\text { periode 2016-2019 }\end{array}$ & 69 \\
2. & $\begin{array}{l}\text { Perusahaan yang tidak menerbitkan laporan keuangan secara lengkap } \\
\text { selama periode 2016-2019 }\end{array}$ & (11) \\
3. $\begin{array}{l}\text { Perusahaan yang tidak mengalami keuntungan secara berturut-turut } \\
\text { selama periode 2016-2019 }\end{array}$ & (20) \\
Jumlah Sampel Perusahaan & 38 \\
\hline
\end{tabular}

Sumber : Data diolah peneliti, 2020

Adapun metode analisis yang digunakan untuk menguji hipotesis dalam penelitian ini yaitu metode statistic deskriptif dengan menggunakan alat analisis Regresi Linear Moderasi. Variabel bebas (independen) dalam penelitian ini yaitu rasio rofitabilitas yang diukur dengan Return On Asset (ROA), rasio likuiditas yang diukur dengan Current Ratio 
(CR) dan ukuran perusahaan yang diukur dengan Ln Total Aset. Variabel terikat (dependen) dalam penelitian ini yaitu Prediksi kebangkrutan. Sedangkan variabel terakhir dalam penelitian ini yaitu Struktur Modal sebagai variabel moderasi yang diukur dengan menggunakan rasio Debt Equity Ratio (DER). Prediksi kebangkrutan dengan menggunakan metode Grover (G-score). Model Grover (G-Score) mengahasilkan persamaan sebagai berikut:

$$
G(\text { Score })=1,650(\mathrm{X} 1)+3,404(\mathrm{X} 2)-0,016(\mathrm{ROA})+0,057
$$

Keterangan :

$\mathrm{X} 1=$ Working Capital / Total Asset

$\mathrm{X} 2=$ Earning Before Interest And Taxes / Total Asset

$\mathrm{ROA}=$ Net Income / Total Asset

Adapun kriteria berdasarkan metode G-Score (Intan, et al. 2016) yaitu jika skor kurang dari atau sama dengan $-0,02(\mathrm{G} \leq-0,02)$ perusahaan dikategorikan bangkrut, jika skor lebih dari atau sama dengan $0,01(G \geq 0,01)$ perusahaan dikategorikan dalam kondisi tidak bangkrut, dan jika skor berada diantara batas atas dan batas bawah maka perusahaan dikategorikan dalam kondisi grey area.

\section{Statistik Deskriptif}

\section{HASIL DAN PEMBAHASAN}

Tabel 2. Rata-rata Statistik Deskriptif

\begin{tabular}{|c|c|c|c|c|}
\hline Variabel & $\mathbf{2 0 1 6}$ & $\mathbf{2 0 1 7}$ & $\mathbf{2 0 1 8}$ & $\mathbf{2 0 1 9}$ \\
\hline ROA & 5,96 & 6,53 & 5,40 & 4,33 \\
\hline CR & 2,29 & 2,20 & 2,11 & 2,53 \\
\hline Ukuran Perusahaan & 14,43 & 14,55 & 14,70 & 14,74 \\
\hline Financial Distrees & 0,65 & 0,63 & 0,65 & 0,60 \\
\hline DER & 1,18 & 1,11 & 1,17 & 1,09 \\
\hline
\end{tabular}

Pada hasil tabel 1. menunjukkan variabel ROA dan CR mengalami fluktuasi. Sedangkan ukuran perusahaan selama empat tahun berturut-turut selalu mengalami kenaikan. Struktur modal yang diproksikan dengan DER juga mengalami fluktuasi setiap tahunnya. Pada tahun 2016 DER mencapai $25.93 \%$ kemudian turun menjadi $24.40 \%$ pada tahun 2017. Di tahun berikutnya yaitu tahun 2018 mengalami kenaikan sebesar $25.71 \%$ dan pada tahun 2019 turun lagi sebesar 23.96\%. Persentase Return on Asset tertinggi diperoleh pada tahun 2017 sebesar 29,39\% dan terendah pada tahun 2019 sebesar $19.49 \%$.

Tabel 2. Statistik Deskriptif Perusahaan Sektor Industri Dasar dan Kimia Descriptive Statistics

\begin{tabular}{|c|r|r|r|r|r|}
\hline & N & Minimum & Maximum & Mean & Std. Deviation \\
\hline ROA & 152 & .01 & 56.00 & 5.5551 & 6.29582 \\
CR & 152 & .70 & 14.41 & 2.2833 & 1.90545 \\
Ukuran Perusahaan & 152 & 11.69 & 18.20 & 14.6064 & 1.53351 \\
Financial Distrees & 152 & .10 & 5.44 & 1.1352 & .94114 \\
DER & 152 & -.71 & 2.85 & .6310 & .42260 \\
Valid N (listwise) & 152 & & & & \\
\hline
\end{tabular}


Data hasil statistik pada tabel 2. menunjukkan sampel, nilai minimum, maximum, mean dan standar deviasi dari seluruh variabel yang digunakan dalam penelitian. ROA dengan nilai minimum 0.01, nilai maksimum 56.00 dan nilai mean (rata-rata) sebesar 5.55. Variabel CR masing-masing dengan nilai minimum, maksimum, dan rata-rata sebesar $0.70,14.41$ dan 2.28. Variabel Ukuran perusahaan diperoleh nilai tertinggi sebesar 18.20, nilai terendah 11.69 dan rata-rata sebesar 14.60. Sedangkan variabel moderasi yaitu DER nilai minimum yang diperoleh -0.71, nilai maksimum 2.85 dan nilai mean 0,63.

\section{Koefisien Determinasi}

Tabel 3. Hasil Uji Koefisien Determinasi

Model Summaryb

\begin{tabular}{|c|r|r|r|r|}
\hline Model & R & R Square & $\begin{array}{c}\text { Adjusted R } \\
\text { Square }\end{array}$ & Std. Error of the Estimate \\
\hline 1 & .527 & .277 & .258 & .36410 \\
\hline
\end{tabular}

a. Predictors: (Constant), DER, Ukuran Perusahaan, ROA, CR

b. Dependent Variable: Financial Distrees

Hasil pada tabel 3. menunjukkan Nilai adjusted R square yaitu sebesar 0,258 atau $25.8 \%$. Hal ini menggambarkan bahwa $25.8 \%$ variabel financial distrees dengan menggunakan metode Grover (G-Score) dapat disebabkan oleh variabel Return on Asset, Current Ratio dan Ln Total Asset. 74,2\% sisanya disebabkan oleh faktor-faktor lain diluar penelitian ini.

\section{Uji t-Test (Parsial)}

Tabel 4. Hasil Uji t-Test

Coefficients $^{a}$

\begin{tabular}{|c|c|c|c|c|c|c|}
\hline \multirow{2}{*}{\multicolumn{2}{|c|}{ Model }} & \multicolumn{2}{|c|}{ Unstandardized Coefficients } & \multirow{2}{*}{$\begin{array}{c}\begin{array}{c}\text { Standardized } \\
\text { Coefficients }\end{array} \\
\text { Beta }\end{array}$} & \multirow[b]{2}{*}{$\mathrm{t}$} & \multirow[b]{2}{*}{ Sig. } \\
\hline & & B & Std. Error & & & \\
\hline 1 & (Constant) & .840 & .311 & & 2.701 & .008 \\
\hline & ROA & -.004 & .005 & -.055 & -.760 & .448 \\
\hline & CR & $.07 \oint$ & .017 & .351 & 4.702 & .000 \\
\hline & Ukuran Perusahaan & -.014 & .020 & -.052 & -.727 & .468 \\
\hline & DER & $-.13 q$ & .034 & -.301 & -4.011 & .000 \\
\hline
\end{tabular}

a. Dependent Variable: Financial Distrees

Berdasarkan tabel 4. hasil uji t tersebut dapat dielaskan bahwa variabel ROA dan ukuran perusahaan yang diproksikan dengan Ln total aset tidak berpengaruh terhadap finanacial distrees karena nilai signifikansi masing-masing variabel lebih kecil dari nilai signifkansi yang diharapkan, dimana ROA dengan nilai signifikansi $0.448>0.05$ dan Ln Total Aset sebesar 0.468. Sedangkan variabel CR dengan koefisien regresi sebesar 0.078, thitung 4.702 dan nilai signifikansi 0.000 lebih kecil dari 0.05 dimana variabel CR memiliki pengaruh positif secara signifikan terhadap prediksi kebangkrutan. 


\section{Uji MRA (Moderated Regression Analysis)}

Tabel 5. Hasil Moderasi Tahap 1

Coefficients ${ }^{\mathrm{a}}$

\begin{tabular}{|c|c|c|c|c|c|c|}
\hline & \multirow[b]{2}{*}{ Model } & \multicolumn{2}{|c|}{ Unstandardized Coefficients } & \multirow{2}{*}{$\begin{array}{c}\text { Standardized } \\
\text { Coefficients }\end{array}$} & \multirow[b]{2}{*}{$\mathrm{t}$} & \multirow[b]{2}{*}{ Sig. } \\
\hline & & $\mathrm{B}$ & Std. Error & & & \\
\hline \multirow[t]{4}{*}{1} & (Constant) & .697 & .073 & & 9.522 & .000 \\
\hline & ROA & .027 & .009 & .397 & 2.820 & .005 \\
\hline & DER & -.087 & .042 & -.193 & -2.046 & .043 \\
\hline & ROA*DER & -.023 & .006 & -.513 & -3.620 & .000 \\
\hline
\end{tabular}

a. Dependent Variable: Financial Distrees

Berdasarkan tabel 5. menunjukkan bahwa beta sebesar - 0,513 bernilai negatif dengan signifikansi 0,000 0,05 yang artinya struktur modal sebagai variabel moderasi mampu memeoderasi secara signifikan pengaruh ROA terhadap financial distrees.

Tabel 6. Hasil Moderasi Tahap 2

Coefficients $^{a}$

\begin{tabular}{|c|c|c|c|c|c|c|}
\hline & \multirow[b]{2}{*}{ Model } & \multicolumn{2}{|c|}{ Unstandardized Coefficients } & \multirow{2}{*}{$\begin{array}{c}\text { Standardized } \\
\text { Coefficients }\end{array}$} & \multirow[b]{2}{*}{$\mathrm{t}$} & \multirow[b]{2}{*}{ Sig. } \\
\hline & & B & Std. Error & & & \\
\hline \multirow[t]{4}{*}{1} & (Constant) & .575 & .083 & & 6.900 & .000 \\
\hline & $\mathrm{CR}$ & .087 & .025 & .393 & 3.494 & .001 \\
\hline & DER & -.114 & .046 & -.255 & -2.494 & .014 \\
\hline & CR*DER & -.007 & .015 & -.051 & -.444 & .657 \\
\hline
\end{tabular}

a. Dependent Variable: Financial Distrees

Berdasarkan tabel 6. menunjukkan bahwa beta sebesar - 0,051 bernilai negatif dengan signifikansi 0,657 $>0,05$ yang artinya struktur modal sebagai variabel moderasi tidak mampu memoderasi dan tidak signifikan pada pengaruh ROA terhadap financial distrees

Tabel 7. Hasil Moderasi Tahap 3

Coefficients $^{\mathbf{a}}$

\begin{tabular}{|c|c|c|c|c|c|c|}
\hline \multirow{2}{*}{\multicolumn{2}{|c|}{ Model }} & \multicolumn{2}{|c|}{ Unstandardized Coefficients } & \multirow{2}{*}{$\begin{array}{c}\begin{array}{c}\text { Standardized } \\
\text { Coefficients }\end{array} \\
\text { Beta }\end{array}$} & \multirow[b]{2}{*}{$\mathrm{t}$} & \multirow[b]{2}{*}{ Sig. } \\
\hline & & $\mathrm{B}$ & Std. Error & & & \\
\hline \multirow[t]{4}{*}{1} & (Constant) & 1.258 & .475 & & 2.650 & .009 \\
\hline & Ukuran Perusahaan & -.029 & .033 & -.104 & -.868 & .387 \\
\hline & DER & -.223 & .342 & -.497 & -.652 & .515 \\
\hline & Ukuran*DER & .003 & .025 & .085 & .112 & .911 \\
\hline
\end{tabular}

a. Dependent Variable: Financial Distrees 
Berdasarkan tabel 7. menunjukkan bahwa beta sebesar 0,085 bernilai positif dengan signifikansi 0,911 > 0,05 yang artinya struktur modal sebagai variabel moderasi tidak mampu memoderasi dan tidak signifikan pada pengaruh ROA terhadap financial distrees.

\section{Pengaruh return on asset terhadap prediksi kebangkrutan}

Melalui hasil uji t-Test diketahui bahwa nilai signifikan sebesar 0,448 >0,05 dengan nilai koefisien $-0,055$. Berdasarkan hasil uji tersebut dapat disimpulkan bahwa variabel ROA tidak berpengaruh secara signifikan terhadap financial distress pada perusahaan sektor industri dan kimia. Dari hasil nilai koefisien ROA sebesar -0,055 menunjukkan bahwa adanya hubungan negatif antara return on asset dengan prediksi financial distress, yang artinya semakin besar nilai ROA maka semakin kecil probabilitas perusahaan mengalami potensi kebangkrutan.

Rasio profitabilitas menunjukkan efisien dan efektifitas penggunaan aset dalam menghasilkan laba. Perusahaan yang memiliki profitabilitas negatif menunjukkan bahwa tidak adanya efisiensi dan efektivitas penggunaan aset dalam menghasilkan laba bersih dari aset yang digunakan perusahaan. Tidak berpengaruhnya ROA terhadap prediksi kebangkrutan diduga karena besarnya nilai ROA yang juga menujukkan aset perusahaan yang lebih kecil dibandingkan dengan laba yang didapatkan sehingga sebagian dari keuntungan tersebut merupakan hasil dari penggunaan hutang (Fitri, 2016). Hasil penelitian ini tidak sejalan dengan penelitian Adinda, et al. (2017) dan Srikalimah (2017) namun sejalan dengan hasil penelitian Lamria (2015), Fitri (2016), dan Kanya et al. (2014) bahwa menemukan bahwa profitabilitas tidak berpengaruh terhadap financial distrees.

\section{Pengaruh current ratio terhadap prediksi kebangkrutan}

Melalui hasil uji t-Test diketahui bahwa nilai signifikan sebesar 0,000 $<0,05$ dengan nilai koefisien 0,351. Berdasarkan hasil uji tersebut dapat disimpulkan bahwa variabel current ratio berpengaruh secara signifikan terhadap financial distress pada perusahaan sektor industri dan kimia. Dari hasil nilai koefisien CR sebesar 0,351 menunjukkan bahwa adanya pengaruh positif antara current ratio dengan prediksi financial distress. Berpengaruhnya current ratio terhadap financial distrees dapat dikatakan bahwa perbandingan antara aset lancar dengan hutang lancar yang dimiliki oleh perusahaan mampu untuk memprediksi kondisi financial distrees. Penelitian ini sejalan dengan hasil penelitian yang dilakukan oleh Stephani et.al (2020), Putra et al (2017), Rahmayanti \& Handromi (2017) yang menyatakan Current Ratio berpengaruh signifikan terhadap financial distrees.

\section{Pengaruh ukuran perusahaan terhadap prediksi kebangkrutan}

Melalui hasil uji t-Test diketahui bahwa nilai signifikan sebesar 0,468 > 0,05 dengan nilai koefisien $-0,052$. Berdasarkan hasil uji tersebut dapat disimpulkan bahwa variabel ukuran prusahaan yang diukur dengan Ln Total Aset tidak berpengaruh secara signifikan terhadap financial distress pada perusahaan sektor industri dan kimia. Dari hasil nilai koefisien ukuran perusahaan sebesar -0,052 menunjukkan bahwa adanya hubungan negatif antara ukuran perusahaan dengan prediksi financial distress, yang artinya semakin besar nilai ukuran perusahaan maka semakin kecil probabilitas perusahaan mengalami potensi kebangkrutan.

Umumnya perusahaan yang besar biasanya lebih mudah memperoleh dana pinjaman dibandingkan dengan perusahaan yang berskala kecil karena adanya tingkat kepercayaan kreditur terhadap perusahaan yang berskala besar (Stephani et.al, 2020). Namun dalam penelitian ini tidak terdapat pengaruh signifikan antara ukuran perusahaan dengan prediksi financal distrees. Hal ini tidak sejalan dnegan penelitian yang dilakukan 
oleh Widhy dan Nadya (2019), Orchid (2014), Ni Wayan dan Ni Ketut (2014), namun sejalan dengan penelitian Fifi (2016), Adinda, et al (2017), dan Srikalimah (2017) yang menemukan bahwa ukuran perusahaan tidak berpengaruh terhadap financial distrees perusahaan.

\section{Pengaruh moderasi struktur modal terhadap return on asset dan prediksi kebangkrutan}

Melalui hasil uji moderasi dapat diketahui bahwa nilai signifikan sebesar $0,000<$ 0,05 dengan nilai koefisien -0,513. Berdasarkan hasil uji tersebut dapat disimpulkan bahwa struktur modal mampu secara signifikan memoderasi hubungan pengaruh return on asset terhadap financial distress pada perusahaan sektor industri dan kimia tahun 2016-2019. Hipotesis 4 uji moderasi dengan varibel struktur modal disini mampu memperkuat pengaruh ROA terhadap financial distrees. Struktur modal yang baik mampu mempengaruhi perolehan laba perusahaan. Struktur modal yang diproksikan dengan rasio debt equity ratio menunjukkan kemampuan perusahaan dalam membayar kewajiban, dimana semakin kecil DER semakin baik kemampuan perusahaan tersebut dalam membayar hutangnya. Hal ini sejalan dengan penelitian Khotimah dan Yuliana (2020) yang mengatakan bahwa struktur modal yang efektif mampu memoderasi (memperkuat) hubungan antara profitabilitas dalam memprediksi kebangkrutan.

\section{Pengaruh moderasi struktur modal terhadap current ratio dan prediksi kebangkrutan}

Melalui hasil uji moderasi dapat diketahui bahwa nilai signifikan sebesar 0,657 > 0,05 dengan nilai koefisien -0,051. Berdasarkan hasil uji tersebut dapat disimpulkan bahwa struktur modal tidak mampu secara signifikan memoderasi hubungan pengaruh current ratio terhadap financial distress pada perusahaan sektor industri dan kimia tahun 2016-2019. Perusahaan yang mampu membayar hutang jangka pendeknya dengan tepat waktu, mempunyai dana internal yang cukup dalam pendanaan perusahaan. Perusahaan akan cenderung menggunakan dana internal dibandingkan dengan dana eksternal ketika dana internal dinilai cukup untuk membayar kewajiban jangka pendeknya sehingga kemungkinan kecil perusahaan akan mengalami potensi kebangkrutan. Akan tetapi, dalam penelitian ini uji moderasi dengan variabel struktur modal yang diproksikan dengan rasio debt equity ratio tidak mampu memperkuat pengaruh current ratio terhadap financial distrees. Hal ini tidak sejalan dengan penelitian yang dilakukan oleh Akmalia (2020), Andre (2013), dan Ardian et.al (2016) yang mengatakan bahwa struktur modal berpengaruh signifikan terhadap financial distrees.

\section{Pengaruh moderasi struktur modal terhadap ukuran perusahaan dan prediksi kebangkrutan}

Melalui hasil uji moderasi dapat diketahui bahwa nilai signifikan sebesar 0,911 > 0,05 dengan nilai koefisien 0,085. Berdasarkan hasil uji tersebut dapat disimpulkan bahwa struktur modal tidak mampu secara signifikan memoderasi hubungan pengaruh ukuran perusahaan terhadap financial distress pada perusahaan sektor industri dan kimia tahun 2016-2019. Ukuran perusahaan merupakan salah satu faktor dalam menentukan keputusan pendanaan (struktur modal) dalam memenuhi besarnya total aktiva atau aset yang dimiliki oleh perusahaan. Perusahaan yang berskala besar biasanya lebih berani untuk mengeluarkan saham-saham baru sehingga semakin besar ukuran perusahaan, semakin besar pula kecendurungan perusahaan menggunakan dana eksternal untuk memenuhi kebutuhan operasionalnya (Jusrical \& Aloysius, 2017). Dalam penelitian ini, uji moderasi dengan varibel struktur modal tidak mampu memperkuat pengaruh ukuran 
perusahaan (Ln total aset) terhadap financial distrees. Hal ini tidak sejalan dengan penelitian yang dilakukan oleh Ardian et.al (2016), Akmalia (2020) dan Andre (2013) yang mengatakan bahwa struktur modal memiliki pengaruh yang signifikan terhadap financial distrees.

Materi pembahasan terutama mengupas apakah hasil yang didapat sesuai dengan hipotesis atau tidak, dan kemukakan argumentasinya. Pengutipan rujukan dalam pembahasan jangan terlalu panjang (bila perlu dihindari). Sitasi hasil penelitian atau pendapat orang lain hendaknya disarikan dan dituliskan dalam kalimat sendiri (tidak menggunakan kalimat yang persis sama). Kumpulan penelitian sejenis dapat dirujuk secara berkelompok.

\section{SIMPULAN}

Variabel profitabilitas yang diproksikan dengan return on asset tidak berpengaruh terhadap financial distress pada perusahaan sektor industri dasar dan kimia yang terdaftar di Bursa Efek Indonesia. Variabel likuiditas yang diproksikan dengan current ratio berpengaruh positif secara signifikan terhadap financial distress pada perusahaan sektor industri dasar dan kimia yang terdaftar di Bursa Efek Indonesia. Variabel ukuran perusahaan yang diproksikan dengan $L n$ total aset tidak berpengaruh terhadap financial distress pada perusahaan sektor industri dasar dan kimia yang terdaftar di Bursa Efek Indonesia. Variabel struktur modal yang diproksikan dengan debt to equity ratio sebagai variabel moderasi mampu memoderasi hubungan return on asset dengan financial distress pada pada perusahaan sektor industri dasar dan kimia yang terdaftar di Bursa Efek Indonesia. Variabel struktur modal yang diproksikan dengan debt to equity ratio sebagai variabel moderasi tidak mampu memoderasi hubungan current ratio dengan financial distress pada pada perusahaan sektor industri dasar dan kimia yang terdaftar di Bursa Efek Indonesia. Variabel struktur modal yang diproksikan dengan debt to equity ratio sebagai variabel moderasi tidak mampu memoderasi hubungan ukuran perusahaan dengan financial distress pada pada perusahaan sektor industri dasar dan kimia yang terdaftar di Bursa Efek Indonesia.

\section{DAFTAR PUSTAKA}

Adindha Sekar Ayu dkk. (2017). Pengaruh Likuditas, Leverage, Profitabilitas, Dan Ukuran Perusahaan Terhadap Financial Distress Studi (pada Perusahaan Manufaktur Sektor Industri Dasar dan Kimia yang Terdaftar di Bursa Efek Indonesia tahun 2012-2015). Jurnal Administrasi Bisnis. 43(1): 138-147

Akmalia, Alien. (2020). Pengaruh Struktur Modal, Struktur Aset, dan Profitabilitas Terhadap Potensi Terjadinya Financial Distrees Perusahaan (Studi pada Perusahaan Manufaktur Sektor Aneka Industri yang erdaftar di Bursa Efek Indonesia Periode 2014-2017). Business Management Analysis Journal (BMAJ). 3(1)

Alam, Intan Syahni, et al. (2016). Analisis Prediksi Kebangkrutan Dengan Menggunakan Metode G-Score, XScore, Dan Z-Score Pada Lembaga Perkreditan Desa Di Kecamatan Buleleng Periode 2013-2014. EJournal Bisma Universitas Pendidikan Ganesha. Vol. 4

Alfinda et.al. (2018). Pengaruh Profitabilitas, Likuiditas Dan Leverage Terhadap Financial Distress (Studi Pada Perusahaan Food \& Beverage Yang Terdaftar Di Bursa Efek Indonesia Periode 2013-2016). Jurnal Administrasi Bisnis (JAB). 61(2)

Al-Khatib, Hazen B. dan Al Al-Horani. (2012). Predicting Financial Distress Of Public Companies Listed In Amman Stock Exchange. European Scientific Journal, 8(15).

Andre, Orina. (2013). Pengaruh Profitabilitas, Likuditas Dan Leverage dalam Memprediksi Financial Distrees (Studi Empiris pada Perusahaan Aneka Industri yang Terdaftar di BEI). Jurnal UNP

Ardian, et. al. (2016). Pengaruh Rasio Likuditas, Rasio Leverage, Rasio Aktivitas dan Rasio Profitabilitas Terhadap Rasio Financial Distress. Semarang: Universitas Pandanaran

Bimawiratma, Patrisius Gerdian. (2016). Analisis Akurasi Metode Altman, Grover, Springate Dan Zmijewski Dalam Memprediksi Perusahaan Delisting (Studi Empiris Pada Perusahaan Manufaktur di Bursa Efek Indonesia Periode 2009-2013). Universitas Sanata Dharma 
Gobenvy, Orchid. (2014). Pengaruh Profitabilitas, Financial Leverage Dan Ukuran Perusahaan Terhadap Financial Distress Pada Perusahaan Manufaktur Yang Terdaftar Di Bursa Efek Indonesia Tahun 20092011. Fakultas Ekonomi Universitas Negeri Padang

Kanya et al. (2014). Prediction on Financial Distress of Mining Companies Listed in BEI using Financial Variables and Non-Financial Variables. European Journal of Business and Management. 6(34) : 226237

Khotimah, Khusnul \& Yuliana, Indah. (2020). Pengaruh Profitabilitas Terhadap Prediksi Kebangkrutan (Financial Distress) Dengan Struktur Modal Sebagai Variabel Moderating. Forum Ekonomi. 22(1): 37 43

Krisnayanti, Ni Wayan \& Merkusiwati, Ni Kt. Lely A. (2014). Pengaruh Mekanisme Corporate Governance, Likuiditas, Leverage, Dan Ukuran Perusahaan Pada Financial Distress. E-Jurnal Akuntansi Universitas Udayana. 7(1) : 93-106

Pratama, Rendra. (2016). Analisis Pengaruh Rasio Keuangan untuk Memprediksi Kondisi Financial Distress Bank Umum Syariah Menggunakan Model Logit di Indonesia. STIE Perbanas Surabaya

Putri, Deanisyah Suryani \& Erinos NR. (2020). Pengaruh Rasio Keuangan, Ukuran Perusahaan, dan Biaya Agensi Terhadap Financial Distress. Jurnal Eksplorasi Akuntansi. 2(1) : 2083-2098

Putra, Y. A. P., et.al (2017). Analisis Rasio Keuangan untuk Memprediksi Kondisi Financial Distress Perusahaan Manufaktur yang Terdaftar di Bursa Efek Indonesia. JIMAT (Jurnal Ilmiah Mahasiswa Akuntansi) Undiksha. 8(2).

Sari, M.P \& Yunita, I. 2019. Analisis Prediksi Kebangkrutan Dan Tingkat Akurasi Model Springate, Zmijewski, Dan Grover Pada Perusahaan Sub Sektor Logam Dan Mineral Lainnya Yang Terdaftar Di Bursa Efek Indonesia Tahun 2012-2016. JIM UPB. 7(1)

Stephanie dkk. (2020). Pengaruh Likuiditas, Leverage Dan Ukuran Perusahaan Terhadap Financial Distress Pada Perusahaan Properti Dan Perumahan The Effect Of Liquidity, Leverage And Size Of The Company Against The Financial Distress Of Property And Real Estate Companies. Journal of Economic, Business and Accounting. 3 (2): 300-310

Srikalimah. (2017). Pengaruh Profitabilitas, Likuiditas dan Leverage Dalam Memprediksi Financial Distress (Studi Empiris Pada Perusahaan Manufaktur yang Terdaftar di BEI Periode 2009-2013). Jurnal Akuntasi \& Ekonomi FE UN PGRI Kediri. 2(1)

Widhy Setyowati dan Nadya Ratna Nanda Sari. (2019). Pengaruh Likuiditas, Operating Capacity, Ukuran Perusahaan Dan Pertumbuhan Penjualan Terhadap Financial Distress (Studi Pada Perusahaan Manufaktur Yang Terdaftar Di Bei Tahun 2016-2017) Jurnal Magisma. VII(2)

Yustika, Yeni. (2015). Pengaruh Likuiditas, Leverage, Profitabilitas, Operating Capacity Dan Biaya Agensi Manajerial Terhadap Financial Distress (Studi Empiris pada Perusahaan Manufaktur yang Terdaftar di Bursa Efek Indonesia Tahun 2011-2013). Jom FEKON. 2(2)

www.mliputan6.com, Diakses pada tanggal 05 Oktober 2020 Pukul 10.00

www.jawapos.com, Diakses pada tanggal 05 Oktober 2020 Pukul 09.00

www.obrolanbisnis.com, Diakses pada tanggal 05 Oktober 202009.00 